\title{
Di-(2-ethylhexyl)-phthalate'e Maruz Kalan Alburnus tarichi (Güldenstädt, 1814) Erken Larvalarında Östrojen Reseptör ve P450 Aromataz mRNA Seviyeleri
}

\author{
Levels of Aromatase and Estrogen Receptors mRNA in Early Larvae of Alburnus \\ tarichi (Güldenstädt, 1814) Exposed to Di-(2-ethylhexyl)-phthalate
}

\section{Güler ÜNAL ${ }^{1}$, Ertuğrul KANKAYA ${ }^{2}$, Burak KAPTANER ${ }^{3}$, Ahmet R. OĞUZ®, Ian P. CALLARD ${ }^{4}$}

\author{
${ }^{1}$ Adnan Menderes University Faculty of Healthy Sciences Department of Child Development, Aydın, Türkiye \\ ${ }^{2}$ Yüzüncü Y1l University Faculty of Fisheries, Van, Türkiye \\ ${ }^{3}$ Yüzüncü Y1l University Faculty of Science Department of Biology, Van, Türkiye \\ ${ }^{4}$ Boston University Department of Biology, Boston, USA
}

ÖZ

\begin{abstract}
Amaç: Bu çalışmanın amacı Alburnus tarichi'nin erken larval gelişimi üzerine fitalatın etkisini belirlemektir.
Yöntem: Erken larval dönemde (yumurtadan çıktıktan 2 gün sonra) 0.1 , 1, ve $10 \mu \mathrm{g} / \mathrm{L}$ fitalat'a, 6 gün, maruz bırakılarak larvalarda östrojen reseptörleri alfa, beta-1 ve beta-2 ve aromataz B ve A'nın mRNA seviyeleri ölçüldü.

Bulgular: Fitalat'in her üç konsantrasyonunda östrojen reseptör alfa, beta1, beta2 ve aromataz B'nin mRNA seviyelerinde belirgin bir değişiklik olmadığı belirlendi. Bununla birlikte aromataz A mRNA seviyesi fitalat'ın $0.1 \mu \mathrm{g} / \mathrm{L}$ uygulamasında belirgin olarak artarken 1 ve $10 \mu \mathrm{g} / \mathrm{L}$ uygulamalarda değişiklik gözlenmedi.

Sonuç: Bu sonuçlar, fitalat'ın çevresel konsantrasyonlarının kısa sureli uygulamalarda, Alburnus tarichi erken larval gelişimi sırasında, steroid sentezindeki genleri önemli seviyede etkilemediğini göstermiştir. Bununla birlikte fitalat'ın gen ekspresyonu üzerindeki etkisini belirlemek için, dış beslenmeyi de içine alan uzun süreli uygulamalı çalışmalara ihtiyaç vardır.
\end{abstract}

Anahtar Kelimeler: Alburnus tarichi, Di-(2-Etilhekzil)- fitalat, Östrojen Reseptör, Gen Ekspresyonu, P450 Aromataz.

ABSTRACT

Objective: The aim of this study is to determine the effect of phthalate on the early larval development of Alburnus tarichi. Methods: The larva (2 days after hatching) of Alburnus tarichi were exposed to $0.1,1$, and $10 \mu \mathrm{g} / \mathrm{L}$ phthalate for 6 days (during yolk sac nutrition), and the levels of estrogen receptor alfa, beta-1 and beta-2, and aromatase B and A mRNA levels were measured.

Results: No difference was found in the estrogen receptor alpha, beta-1, beta-2, and aromatase-B mRNA levels with all 3 concentrations of phthalate. However, the aromatase-A mRNA level was significantly increased with $0.1 \mu \mathrm{g} / \mathrm{L}$ of phthalate, while no changes were observed with 1 and $10 \mu \mathrm{g} / \mathrm{L}$ of phthalate.

Conclusion: These results suggest that short-time expose to environmentally relative concentrations of phthalate do not significantly affect genes in steroid synthesis during the early larval development of Alburnus tarichi. However, long-term applied studies including external nutrition are need to determination the effect of phthalate on steroid gene expression.

Key words: Alburnus tarichi, Di-(2-ethylhexyl)-phthalate, Estrogen Receptor, Gene Expression, P450 Aromatase.

Corresponding author: Guler Unal

Adnan Menderes University, Department of Child Development, Faculty of Healthy Sciences, Center Campus, EfelerAydın, TURKEY

histoloji35@gmail.com

Received: 01.08.2019 - Accepted: 31.01.2020 


\section{INTRODUCTION}

Endocrine disrupters are a large group of man-made chemicals that enter the environment in different ways, such as industry, wastewater treatment plants, and agricultural and human waste, and they can have a serious impact on humans and wildlife by interfering with their endocrine functions.

Di-(2-ethylhexyl)-phthalate (DEHP) is widely used as a plasticizer in flexible vinyl products. Plastics may contain from $1 \%$ to $40 \%$ DEHP by weight and are used in consumer products, such as food packaging materials, children's toys, container for blood products and transfusion, insecticide carries, liquid detergents, component of cosmetic products, clothing and car products, and so on. Hence, DEHP is the most comment pollutant chemical of our general environment, and it has the potential to accumulate in soil, sediments, underground water, and air due to its low soluble and vaporization abilities. Domestic and industrial wastewater treatment plants (1) in landfill leachates and the effluent from leachate treatment facilities (2) are the major source of DEHP contaminants in fresh water such as rivers and lakes. Most studies have shown that DEHP has been found to exist in freshwater and sediments $(3,4)$, as well as in agricultural soils (5).

Studies have shown that DEHP causes adverse effects on human reproduction and health (6,7). Di-(2-ethylhexyl)-phthalate has an anti-androgenic activity and leads to reproductive abnormalities by decreasing the testosterone synthesis in fetal testis (8). In fish, mixed results have been reported regarding the effects of DEHP on reproduction. Di-(2ethylhexyl)-phthalate has been shown to weaken estrogenic activity in fish cell culture (9). In Japanese medaka (Oryzias latipes), DEHP has shown anti-estrogenic activity in female fish, while no adverse effects have been observed in male fish $(10,11)$. However, some studies have shown that DEHP has adverse effects on the reproductive system of male fish $(12,13)$. In general, these effects depend on the concentration of the DEHP and exposure time. However, fish are more sensitive to DEHP during early development than in the adult stage (14-17).

Estrogen receptors (ER $\alpha, E R \beta 1$, and $E R \beta 2)$ and $\mathrm{P} 450$ aromatase (P450arom) isomers (CYP19A and CYP19B) have a more important role in gonadal development during early embryonic life in fish (18-20). Endocrine disrupting chemicals (EDCs) can alter gene expression via endogen receptors. Wildlife and laboratory studies have shown that EDCs are response for reproductive abnormalities (21-24). CYP19 is a key enzyme in the steroidogenesis pathway, which is catalyzed by the conversion of androgen into estrogens. In all of the studied fish, there are 2 different P450arom isomers (brain-derived CYP19B and ovary-derived CYP19A), and they have different structures and functions $(25,26)$. Changes in the ER $\alpha, \mathrm{Vtg}$, and P450 aromatase (especially Cyp19b) mRNA levels are an accepted indicator of environment xenoestrogens $(27,28)$. In our previous study, DEHP was indicated in sediment from Lake Van (29).

The aim of this study was to indicate the effects of ER $\alpha, E R \beta 1, E R \beta 2, C Y P 19 B$, and CYP19A on gene expression during the larval development (during yolk sac feeding) of Alburnus tarichi. A. tarichi is an endemic cyprinid species to Lake Van Basin, in Turkey, and only this fish has adapted to Lake Van which is an alkaline lake with a Ph of 9.4-9.8. 


\section{MATERIALS AND METHOD}

\section{Chemicals}

The DEHP (purity $\geq 99.5 \%$ ) used in the experiments was purchased from Sigma Aldrich, St. Louis, MO, USA). A stock solution of $1 \mathrm{mg} / \mathrm{mL}$ in dimethylsulfoxide was prepared. This solution was further diluted with rested tap water to nominal concentrations of $0.1,1$, and 10 $\mu \mathrm{g} / \mathrm{L}$ of DEHP prepared immediately before use. Reproductively mature female and male A. tarichi were collected from Karasu river (May 12, 2013) and transferred to the lab. Fish were keep in a big tank with airing using dechlorided water $(60 \mathrm{~L})$ at room temperature $\left(17^{\circ} \mathrm{C}\right)$ and at natural a light/dark photoperiod of $13: 11$ for 1 day to be relaxed. The fertilizing and embryonic developing were carried out in a small aquarium, as previously described (30). The hatching larvae were transferred to in glass beakers containing $250 \mathrm{~mL}$ water. A total of 100 larvae were put into each beaker and they were exposed to nominal concentrations of $0.1,1$, and $10 \mu \mathrm{g} / \mathrm{L}$ of DEHP in aired conditions at room temperature. In addition to the water control, a solvent vehicle control $(2.5 \mu \mathrm{L})$ was also added. The treatment of 1 and 2 and days old larvae was canceled because one larva was died 1 day on third day. So, it was used 2 days old larvae. The treatments of each concentration and the controls were performed in duplicate with replacement of the media every $24 \mathrm{~h}$. When the yolk proteins were almost completely absorbed and before starting external nutrition, the treatment was stopped (after 6 days). For each sample, 18 larvae were pooled and treated with RNAlater (Sigma), frozen at $-80{ }^{\circ} \mathrm{C}$, and shipped to Boston University, Boston, MA, USA on dry ice and stored at $-80{ }^{\circ} \mathrm{C}$ until RNA extraction was performed.

\section{RNA Extraction and Gene Expression Analysis}

The total RNA was extracted from frozen larvae using Trizol (Sigma Aldrich St. Lous, MO) according to the manufacturer's instructions. RNAs were run on a 1\% agarose gel to assess the quality, and the total RNA was quantified using a Nanodrop (Thermo Fisher Scientific). cDNAs were obtained with $5 \mu \mathrm{g}$ of total RNA using SuperScript II transcriptase and oligo (dT)18 primer according to the manufacturer's instructions (Invitrogen).

Real-time quantitative PCR (qPCR) primers, which were previously designed, were used (29). An amplification efficiency value was obtained for each primer using serial dilutions of the sample. The reverse transcribed mRNA was measured by the qPCR using target-specific assays. The qPCR was performed on an ABI Prism 7900HT sequence detection system (Applied Biosystems) with a SYBR ${ }^{\circledR}$ green fluorescent label. $\beta$-actin, the reference gene, was used as an internal control to normalize the mRNA expression values.

\section{Data Analysis}

Data deduced by the qPCR were first analyzed using the Applied Biosystems Sequence Detection System 2.2.1. Analyses were conducted with qGene to normalize the data obtained. Relative quantification was performed by a modified comparative critical threshold method that corrects for different PCR amplification efficiencies among primer pairs (31). The normalized gene expression is given as the mean normalized expression $(\mathrm{MNE})=($ EPPlmeanCTPP1 $) / \mathrm{E}$ ER $\alpha$ meanCTER $\alpha$, where $E=$ the PCR efficiency $(E=10-(1 /$ slope $)$ ) and the mean threshold cycle $(\mathrm{CT})$ is the average CT from the 3 replicates (32). Data were rejected if the SEM 
percentage was greater than $20 \%$. The average MNE was determined for each set of replicates obtained from an individual animal, and the standard deviation was calculated for each SEM of the MNE. The MNEs were then averaged for each group analyzed. Statistical analyses (Student's $t$ test and 1-way ANOVA) were performed using the SAS 9.2 package. Significance was set at $\mathrm{P}<0.05$.

\section{RESULTS}

We measured the ER $\alpha, E R \beta 1, E R \beta 2, C Y P 19 B$, and CYP19A mRNA levels of larval of A. tarichi exposed to concentrations of $0.1,1$, and $10 \mu \mathrm{g} / \mathrm{L}$ of DEHP. No differences were found between just the water and with the solvent controls. The ER $\beta 1$ mRNA transcript did not change at all with the treated concentrations ( $\mathrm{P}>0.05)$. The levels of ER $\alpha$ and ER $\beta 2 \mathrm{mRNA}$ increased with 0.1 and $1 \mu \mathrm{g} / \mathrm{L}$ of DEHP, but they were not significantly important (Figure $1 ; \mathrm{P}>0.05$ ). Moreover, no differences were found in the expression of CYP19B with any of the treated concentrations. However, the level of CYP19A mRNA significantly increased with $0.1 \mu \mathrm{g} / \mathrm{L}$ of DEHP, while no difference was found with 1 and $10 \mu \mathrm{g} / \mathrm{L}$ of DEHP (Figure 2; P>0.05).

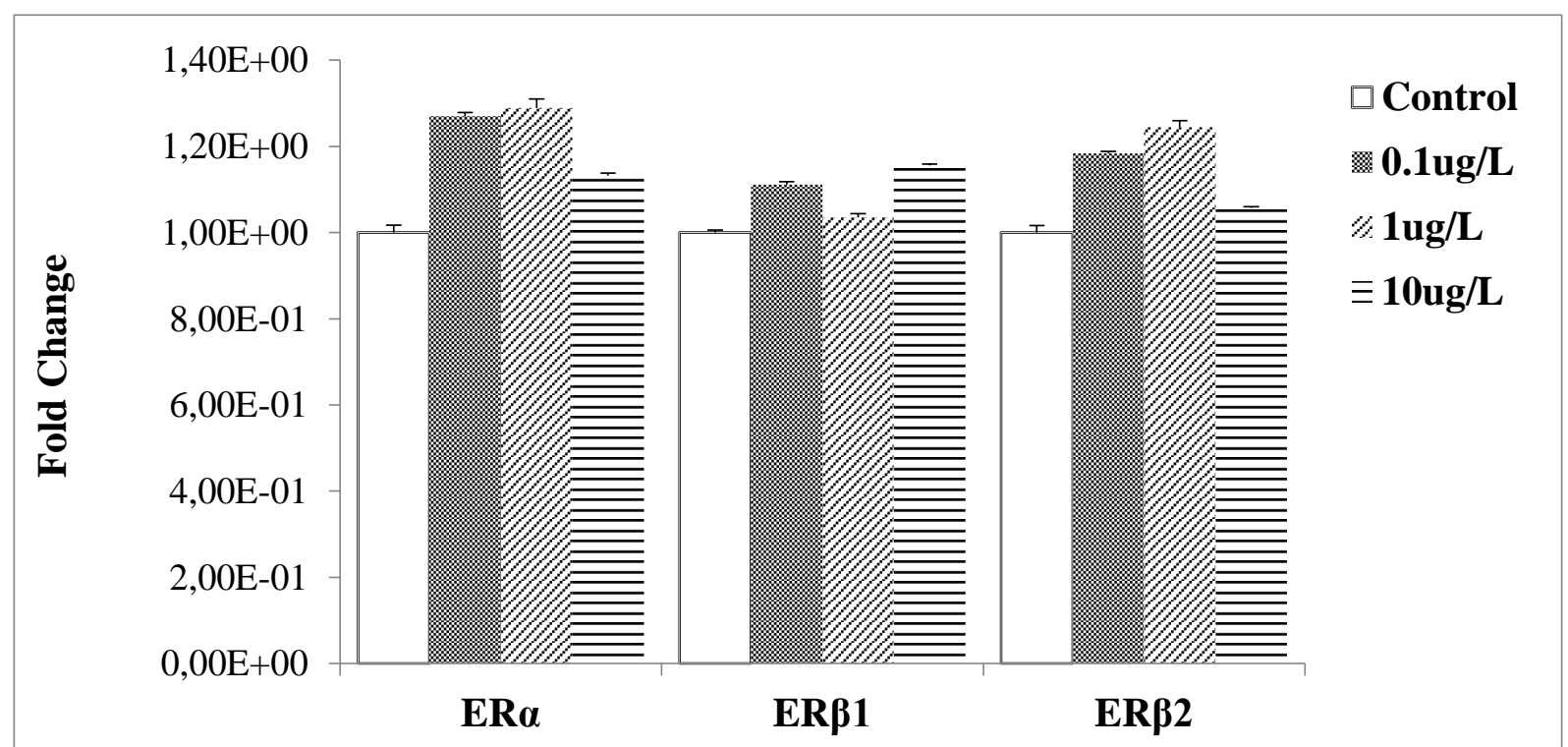

Figure 1. Relative mRNA transcript expressions of the ER of early larval A. tarichi exposed to $0.1,1$, and 10 $\mu \mathrm{g} / \mathrm{L}$ for 6 days. Gene transcription changes are expressed as the fold change relative to the corresponding control. The results are the mean \pm standard error of the mean of 4 samples. $\mathrm{P}<0.05$ indicates a significant difference between the DEHP exposure groups and the corresponding control.

\section{DISCUSSION}

The present study used early larval A. tarichi to assess the impacts of environmentally relevant concentrations of DEHP. For this, the gene transcriptions of the ERs and aromatase isomers were measured. We found that DEHP at low concentrations with short-time exposure did not affect the gene expression of the ERs and CYP19B in A. tarichi larvae. However, the CYP19A gene was sensitive with $0.1 \mu \mathrm{g} / \mathrm{L}$ of DEHP. DEHP was first accepted as an EDC with weak estrogenic activity using an in vivo assay by Jobling et al. (9). Phthalate ester plasticizers are accepted as anti-androgenic in mammals (8). There are mixed results in fish. However, the 


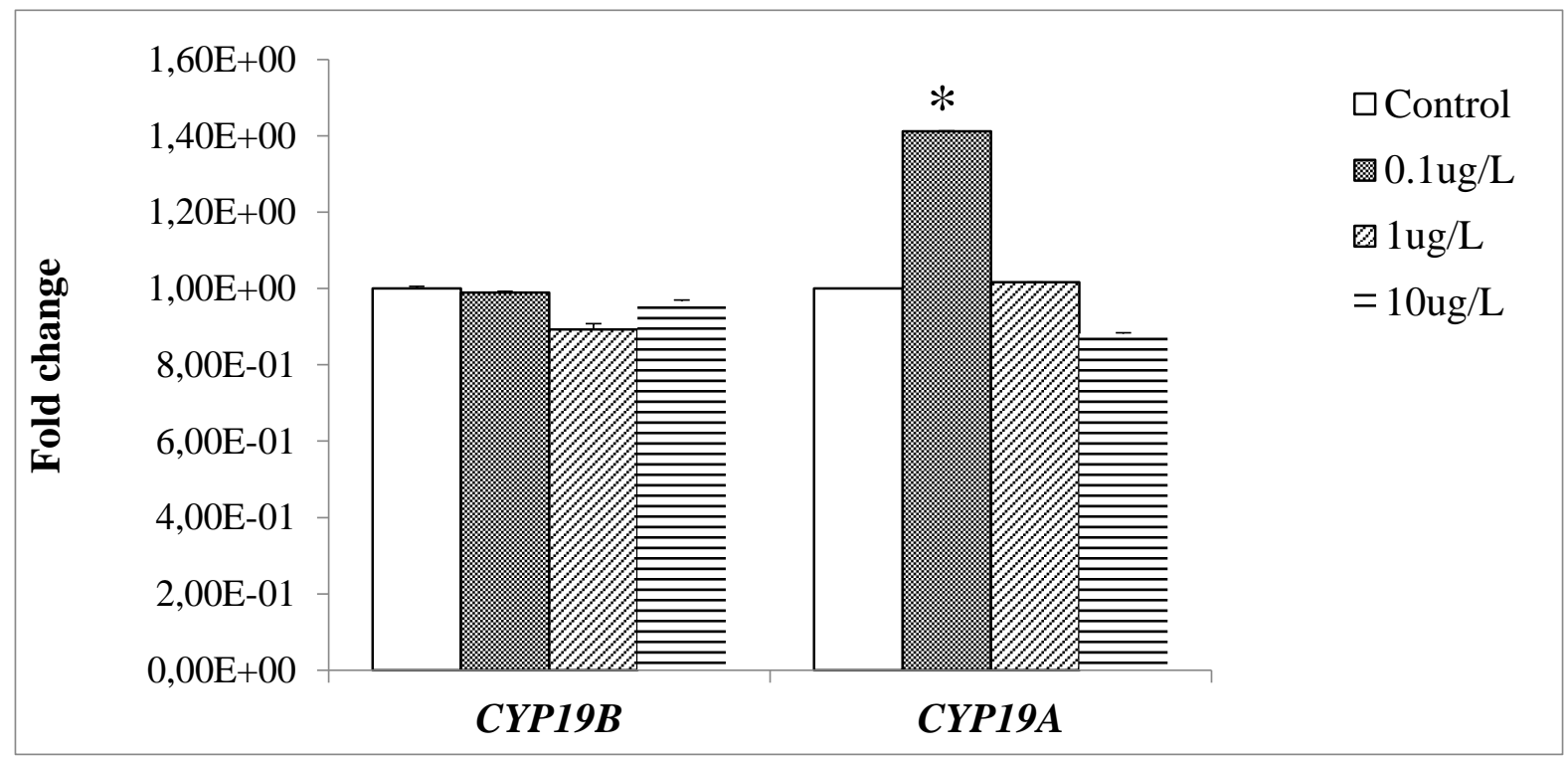

Figure 2. Relative mRNA transcript expressions of the CYP19-arom of early larval A. tarichi exposed to $0.1,1$, and $10 \mu \mathrm{g} / \mathrm{L}$ for 6 days. Gene transcription changes are expressed as the fold change relative to the corresponding control. The results are the mean \pm standard error of the mean of 4 samples. $\mathrm{P}<0.05$ indicates a significant difference between the DEHP exposure groups and the corresponding control.

results in the studied fish have shown that DEHP has had adverse effects on embryos, growth, behavior, and reproductive ability depending on the concentration and exposure time $(11,12,15,16,33,34)$. We used 2-day larvae in the experiment because one of the one day larvae died in $10 \mu \mathrm{g} / \mathrm{L}$ concentration. Fish are more sensitive to the effects of chemicals during early developmental stages compared to maturity. However, in male zebrafish (35), male fathead minnow (36), and Chinese rare minnow (37), the expressions of ERs and aromatase mRNA transcripts did not change with environmentally relative concentrations (12 and $12.8 \mu \mathrm{g} / \mathrm{L})$ of DEHP. Similar to these results, no difference was found in the mRNA transcript levels of ER $\alpha$, ER $\beta 1, E R \beta 2$, and CYP19B in early larval A. tarichi. However, a significant increase in CYP19A of $0.1 \mu \mathrm{g} / \mathrm{L}$ was observed. This increase may be related gonadal development. Generally, CYP19B plays a role in sex differentiation in early embryonic development in fish (38), while CYP19A is involved in ovarian differentiation $(39,40)$ and gametogenesis $(41)$. Moreover, CYP19B expression (not CYP19A) is up-regulated by E2 and environment xenoestrogens $(25,27,42)$ because of CYP19B has estrogen-responsive elements (43). Hence, laboratory and wildlife studies have shown that the changes in Cyp19b indicate estrogenic activity or contaminations. In the present study, the CYP19A mRNA transcript increased in larval A. tarichi exposed to $0.1 \mu \mathrm{g} / \mathrm{L}$ DEHP. However, the CYP19B mRNA transcript remained unchanged in A. tarichi. Our results support the Wang et all. (37)'s hypothesis that DEHP changes plasma sex hormone levels at higher concentrations (>39.4 mg/L) than environmental concentration. We can also say that short-term exposure to environmental concentrations of DEHP did not directly affect estrogenic or anti-estrogenic activity during the early larval life of A. tarichi. However, it may induce gonadal development during early development life in A. tarichi. Therefore, further research is required to indicate the long-term effects on the life and gonadal development in fish exposed to DEHP. 


\section{CONCLUSION}

Gene transcription measurements of the ERs and CYP19arom isomers indicated that 6 days of exposure to environmentally relevant concentrations of DEHP did not result in altered estrogenic or anti-estrogenic effects during the early larval life of A. tarichi.

\section{Acknowledgments}

This work was supported by the Scientific Research Projects of Yuzuncu Yil Univesity (number 2013-HIZ-FEN003). We want to thank Kellie A. Cotter and Rebecca Meyer for their technical advice.

\section{REFERENCES}

1. Marttinen, S. K., Kettunen, R. H., Sormunen, K. M., \& Rintala, J. A. (2003). Removal of bis (2-ethylhexyl) phthalate at a sewage treatment plant. Water Research, 37(6), 1385-1393.

2. Asakura, H., Matsuto, T., \& Tanaka, N. (2004). Behavior of endocrine-disrupting chemicals in leachate from MSW landfill sites in Japan. Waste Management, 24(6), 613-622.

3. Yuwatini, E., Hata, N., \& Taguchi, S. (2006). Behavior of di (2-ethylhexyl) phthalate discharged from domestic waste water into aquatic environment. Journal of Environmental Monitoring, 8(1), 191-196.

4. Yuwatini, E., Hata, N., Kuramitz, H., \& Taguchi, S. (2013). Effect of salting-out on distribution behavior of di (2-ethylhexyl) phthalate and its analogues between water and sediment. SpringerPlus, 2(1), 422.

5. Xu, G., Li, F., \& Wang, Q. (2008). Occurrence and degradation characteristics of dibutyl phthalate (DBP) and di-(2-ethylhexyl) phthalate (DEHP) in typical agricultural soils of China. Science of the Total Environment, 393(2-3), 333-340.

6. Latini, G., De Felice, C., Presta, G., Del Vecchio, A., Paris, I., Ruggieri, F., et al. (2003). In utero exposure to di-(2-ethylhexyl) phthalate and duration of human pregnancy. Environmental health perspectives, 111(14), 1783-1785.

7. Hokanson, R., Hanneman, W., Hennessey, M., Donnelly, K. C., McDonald, T., Chowdhary, R., et al. (2006). DEHP, bis (2)-ethylhexyl phthalate, alters gene expression in human cells: possible correlation with initiation of fetal developmental abnormalities. Human \& experimental toxicology, 25(12), 687-695.

8. Hauser, R., \& Calafat, A. M. (2005). Phthalates and human health. Occupational and environmental medicine, 62(11), 806-818.

9. Jobling, S., Reynolds, T., White, R., Parker, M. G., \& Sumpter, J. P. (1995). A variety of environmentally persistent chemicals, including some phthalate plasticizers, are weakly estrogenic. Environmental health perspectives, 103(6), 582-587.

10. Kim, E. J., Kim, J. W., \& Lee, S. K. (2002). Inhibition of oocyte development in Japanese medaka (Oryzias latipes) exposed to di-2-ethylhexyl phthalate. Environment International, 28(5), 359-365.

11. Shioda, T., \& Wakabayashi, M. (2000). Effect of certain chemicals on the reproduction of medaka (Oryziaslatipes). Chemosphere, 40(3), 239-243.

12. Zanotelli, V. R., Neuhauss, S. C., \& Ehrengruber, M. U. (2010). Long-term exposure to bis (2-ethylhexyl) phthalate (DEHP) inhibits growth of guppy fish 
(Poecilia reticulata). Journal of Applied Toxicology: An International Journal, 30(1), 29-33.

13. Hatef, A., Alavi, S. M. H., Milla, S., Butts, I. A., Rodina, M., Carnevali, O., et al. Di-(2-ethylhexyl)-phthalate Impairs Sperm Quality In Goldfish Associated With Disruption In Androgenesis. Sperm Functions Impairments and Steroidogenesis Transcriptomic Alternations in Fish Exposed to Endocrine Disrupting Chemicals.

14. Chikae, M., Hatano, Y., Ikeda, R., Morita, Y., Hasan, Q., \& Tamiya, E. (2004). Effects of bis (2-ethylhexyl) phthalate and benzo [a] pyrene on the embryos of Japanese medaka (Oryzias latipes). Environmental toxicology and pharmacology, 16(3), 141-145.

15. Chikae, M., Ikeda, R., Hatano, Y., Hasan, Q., Morita, Y., \& Tamiya, E. (2004). Effects of bis (2-ethylhexyl) phthalate, $\gamma$-hexachlorocyclohexane, and $17 \beta$-estradiol on the fry stage of medaka (Oryzias latipes). Environmental toxicology and pharmacology, 18(1), 9-12.

16. Norman, A., Börjeson, H., David, F., Tienpont, B., \& Norrgren, L. (2007). Studies of uptake, elimination, and late effects in Atlantic salmon (Salmo salar) dietary exposed to di-2-ethylhexyl phthalate (DEHP) during early life. Archives of environmental contamination and toxicology, 52(2), 235-242.

17. Lee, J. T., \& Liang, H. H. (2011). Preliminary Study on Zebra Fish's DNA Exposure to Di-2-ethylhexyl Phthalate Effects. Journal of Water Sustainability, 1(3), 323-331.

18. Greytak, S. R., \& Callard, G. V. (2007). Cloning of three estrogen receptors (ER) from killifish (Fundulus heteroclitus): differences in populations from polluted and reference environments. General and comparative endocrinology, 150(1), 174188.

19. Halm, S., Martınez-Rodrıguez, G., Rodrıguez, L., Prat, F., Mylonas, C. C., Carrillo, M., et al. (2004). Cloning, characterisation, and expression of three oestrogen receptors $(E R \alpha, E R \beta 1$ and $E R \beta 2)$ in the European sea bass, Dicentrarchus labrax. Molecular and cellular endocrinology, 223(1-2), 63-75.

20. Nagler, J. J., Cavileer, T. D., Verducci, J. S., Schultz, I. R., Hook, S. E., \& Hayton, W. L. (2012). Estrogen receptor mRNA expression patterns in the liver and ovary of female rainbow trout over a complete reproductive cycle. General and comparative endocrinology, 178(3), 556-561.

21. Ankley, G. T., Kahl, M. D., Jensen, K. M., Hornung, M. W., Korte, J. J., Makynen, E. A., et al. (2002). Evaluation of the aromatase inhibitor fadrozole in a short-term reproduction assay with the fathead minnow (Pimephales promelas). Toxicological sciences, 67(1), 121-130.

22. Hoffmann, J. L., Torontali, S. P., Thomason, R. G., Lee, D. M., Brill, J. L., Price, B. B., et al. (2006). Hepatic gene expression profiling using Genechips in zebrafish exposed to $17 \alpha$-ethynylestradiol. Aquatic Toxicology, 79(3), 233-246.

23. Jobling, S., Beresford, N., Nolan, M., Rodgers-Gray, T., Brighty, G. C., Sumpter, J.P., et al. (2002). Altered sexual maturation and gamete production in wild roach (Rutilus rutilus) living in rivers that receive treated sewage effluents. Biology of reproduction, 66(2), 272-281.

24. Katsu, Y., Lange, A., Urushitani, H., Ichikawa, R., Paull, G. C., Cahill, L. L., et al.(2007). Functional associations between two estrogen receptors, environmental estrogens, and sexual disruption in the roach (Rutilus rutilus). Environmental science \& technology, 41(9), 3368-3374. 
25. Kishida, M., \& Callard, G. V. (2001). Distinct cytochrome P450 aromatase isoforms in zebrafish (Danio rerio) brain and ovary are differentially programmed and estrogen regulated during early development. Endocrinology, 142(2), 740-750.

26. Lange, A., Katsu, Y., Ichikawa, R., Paull, G. C., Chidgey, L. L., Coe, T. S., et al. (2008). Altered sexual development in roach (Rutilus rutilus) exposed to environmental concentrations of the pharmaceutical 17 $\alpha$-ethinylestradiol and associated expression dynamics of aromatases and estrogen receptors. Toxicological Sciences, 106(1), 113-123.

27. Kishida, M., McLellan, M., Miranda, J. A., \& Callard, G. V. (2001). Estrogen and xenoestrogens upregulate the brain aromatase isoform (P450aromB) and perturb markers of early development in zebrafish (Danio rerio). Comparative Biochemistry and Physiology Part B: Biochemistry and Molecular Biology, 129(23), 261-268.

28. Kazeto, Y., Place, A. R., \& Trant, J. M. (2004). Effects of endocrine disrupting chemicals on the expression of CYP19 genes in zebrafish (Danio rerio) juveniles. Aquatic toxicology, 69(1), 25-34..

29. Unal, G., Marquez, E. C., Feld, M., Stavropoulos, P., \& Callard, I. P. (2014). Isolation of estrogen receptor subtypes and vitellogenin genes: expression in female Chalcalburnus tarichi. Comparative Biochemistry and Physiology Part B: Biochemistry and Molecular Biology, 172, 67-73.

30. Ünal, G., Çetinkaya, O., \& Elp, M. (2000). The embryonic and larval development of Chalcalburnus tarichi (Cyprinidae): An endemic fish species of the lake Van basin, Turkey. Bull. of Pure and Appl. Sci. A, 19, 27-41.

31. Simon, P. (2003). Q-Gene: processing quantitative real-time RT-PCR data. Bioinformatics, 19(11), 1439-1440.

32. Pfaffl, M. W. (2001). A new mathematical model for relative quantification in realtime RT-PCR. Nucleic acids research, 29(9), e45-e45.

33. Barse, A.V., Chakrabarti, T., Ghosh, T. K., Pal, A. K., \& Jadhao, S. B. (2007). Endocrine disruption and metabolic changes following exposure of Cyprinus carpio to diethyl phthalate. Pesticide biochemistry and physiology, 88(1), 36-42.

34. Carnevali, O., Tosti, L., Speciale, C., Peng, C., Zhu, Y., \& Maradonna, F. (2010). DEHP impairs zebrafish reproduction by affecting critical factors in oogenesis. PLoS One, 5(4).

35. Uren-Webster, T. M., Lewis, C., Filby, A. L., Paull, G. C., \& Santos, E. M. (2010). Mechanisms of toxicity of di (2-ethylhexyl) phthalate on the reproductive health of male zebrafish. Aquatic toxicology, 99(3), 360-369.

36. Crago, J., \& Klaper, R. (2012). A mixture of an environmentally realistic concentration of a phthalate and herbicide reduces testosterone in male fathead minnow (Pimephales promelas) through a novel mechanism of action. Aquatic toxicology, 110, 74-83.

37. Wang, X., Yang, Y., Zhang, L., Ma, Y., Han, J., Yang, L., et al. (2013). Endocrine disruption by di-(2-ethylhexyl)-phthalate in Chinese rare minnow (Gobiocypris rarus). Environmental toxicology and chemistry, 32(8), 1846-1854.

38. Forlano, P. M., Deitcher, D. L., Myers, D. A., \& Bass, A. H. (2001). Anatomical distribution and cellular basis for high levels of aromatase activity in the brain of teleost fish: aromatase enzyme and mRNA expression identify glia as source. Journal of Neuroscience, 21(22), 8943-8955.

39. Kwon, J. Y., McAndrew, B. J., \& Penman, D. J. (2001). Cloning of brain aromatase gene and expression of brain and ovarian aromatase genes during sexual differentiation in genetic male and female Nile tilapia Oreochromis 
niloticus. Molecular Reproduction and Development: Incorporating Gamete Research, 59(4), 359-370.

40. Matsuoka, M. P., van Nes, S., Andersen, Ø., Benfey, T. J., \& Reith, M. (2006). Real-time PCR analysis of ovary-and brain-type aromatase gene expression during Atlantic halibut (Hippoglossus hippoglossus) development. Comparative Biochemistry and Physiology Part B: Biochemistry and Molecular Biology, 144(1), 128-135.

41. Goto-Kazeto, R., Kight, K. E., Zohar, Y., Place, A. R., \& Trant, J. M. (2004). Localization and expression of aromatase mRNA in adult zebrafish. General and comparative endocrinology, 139(1), 72-84.

42. Sawyer, S. J., Gerstner, K. A., \& Callard, G. V. (2006). Real-time PCR analysis of cytochrome P450 aromatase expression in zebrafish: gene specific tissue distribution, sex differences, developmental programming, and estrogen regulation. General and comparative endocrinology, 147(2), 108-117.

43. Callard, G. V., Tchoudakova, A. V., Kishida, M., \& Wood, E. (2001). Differential tissue distribution, developmental programming, estrogen regulation and promoter characteristics of cyp19 genes in teleost fish. The Journal of steroid biochemistry and molecular biology, 79(1-5), 305-314. 